\title{
Experimental Measurement of Isothermal Sorption, Microbiological and Physicochemical Analysis of Dried Tomatoes Cultivated in Adrar, Algeria
}

\author{
Akil Loumani ${ }^{2 *}$, Ahmed Amine Larbi ${ }^{1}$, Ahmed Mediani ${ }^{1}$, Wafa Braham Chaouch ${ }^{1}$, Houcine Moungar ${ }^{1}$, Cherif \\ Tigani $^{1}$, Foullanine Meriama ${ }^{1}$, Abdelkarim Djaber ${ }^{1}$, Ahmed Mohamed Ali Bekada ${ }^{3}$ \\ ${ }^{1}$ Unité de Recherche en Energies Renouvelables en Milieu Saharien, URERMS, Centre de Développement Des Energies \\ Renouvelables, CDER 01000, Adrar, Algeria \\ ${ }^{2}$ Laboratory of Food and Industrial Microbiology, University of Oran1 Ahmed Ben Bella, Oran 31000, Algeria \\ ${ }^{3}$ Department of Biology, El-Wancharissi University Center, Tissemsilt 38000, Algeria
}

Corresponding Author Email: aki1076@live.fr

https://doi.org/10.18280/ijdne.150514

Received: 20 February 2020

Accepted: 11 July 2020

\section{Keywords:}

hygienic quality, product, conservation, drying solar, gravimetric method, isosteric heats, tomato, GAB and bet models

\begin{abstract}
The fresh tomato is a very perishable product in arid regions for that the drying is an indsipendable technique to preserve this product and used at all times, in this study the fresh tomatoe was sampled from different farms in Adrar and subjected to the drying method using an indirect dryer solar. The dried tomatoes were screened for microbiological and physicochemical analysis including E. coli, Staphylococcus aureus, Salmonella Typhi, anaerobic sulfito- redactors, molds and yeasts in addition, the value of $\mathrm{pH}$, water activity, dry matter, and assay of ash. The obtained results showed the presence of mesophilic aerobic total bacteria, and coliform total, the absence of Salmonella Typhi, Staphylococcus aureus, Clostridium perfringens and spores of anaerobic sulfito reducting and some colonies of yeasts, for the $\mathrm{pH}$ value, activity water, dray matter and assay of ash, the results were $(4.10),(0.41),(9.63 \%)$ and $(5.71 \%)$ respectively, which do not affect the final quality of the dried products and satisfactory to norms imposed by the commercial legislation of Algerian. On the other hand, the isothermal sorption is indispensable step to mastering the process of drying tomatoes, and to know the distribution and the intensity of the water connections in the products as a result, this experimental study aims to determine the physicochemical components' and the desorption isotherms curves for tomato harvested from the Touat region, in South-West Algeria, using the saturated salt solution method. The experiment is carried out for three temperature values $40^{\circ} \mathrm{C}, 50^{\circ} \mathrm{C}$ and $60^{\circ} \mathrm{C}$, to study the influence of the temperature on the equilibrium curves of the product and finally to describe the isothermal moisture desorption for tomato product for three temperatures using known models of GAB, GAB, modified BET who showing the best models isotherms sorption to model at and predict hygroscopic behavior during drying and storage. The results of this research can be used to determine characteristic drying curves and to have optimal storage conditions.
\end{abstract}

\section{INTRODUCTION}

The tomato (Lycopersicon esculetum) is an annual plant of the Solanaceae family, native to northwestern South America, and is a product more generally marketed around the world. The term also refers to this fleshy fruit, which is one of the most important foods in the human diet and is consumed fresh or processed [1]. It is the most consumed cooking ingredient in the world after the potato. It is cultivated in almost all latitudes, covering an area of about 3 million hectares, which represents nearly one-third of the world's surface devoted to vegetables $[1,2]$. Seasonal post-harvest losses of fruits and vegetables are rich in the tropics because of the warmth of the environment and moisture levels [3]. For example, in Togo, this loss represents up to $50 \%$ of tomato production per year. There is a high production of tomato fruit during harvest time, but post-harvest processing and preservation techniques are. ineffective [4] As a result, fruit spoils very early because of the lack of appropriate conservation and processing systems, which leads us to search for different preservation technologies and to allow these products to be available at any time $[3,4]$.

Among these methods Technology, the solar drying, which is an important process that almost all developing countries use to conserve their food. The benefits of drying are the reduction of post-harvest losses, development of a new product to use the tomato outside the production period, diversification of forms of consumption improvement of the incomes of producers and stakeholders in the sector [5].

In other hand the problem that posed is the safety of these dried products and especially related to contamination by microorganisms such as Escherichia coli, Salmonella Shigella, Yersinia vibrio, Clostridium perfringens, and Yersinia enterolitica. Therefore, the objectives of this study were conserved the tomatoes harvest by the drying method using an indirect solar dryer and investigate important spoilage bacteria such as E. coli, Staphylococcus aureus, Salmonella Typhi, anaerobic sulfito-redactors, molds and yeasts and physiochemical characteristics important including $\mathrm{pH}$, water activity, dry matter, and an assay of ash. 
Sorption isotherms are of great importance in the food industry, especially in solar drying, storage and food Preservation [6]. Where inform us about the hygroscopic or hydric balance of the product under consideration, the Isosteric heats, and the lifetime's duration. We do not know the product stability types. This equilibrium is characterized by these curves whose experimental determination requires a large number of measurements [7]. Indeed, the sorption isotherms are indispensable measurement before the process of drying in order to preserve the seasonal post-harvest losses [3]. The knowing of this technique permits to have an overview for the hygroscopic or hydric balance of the product under consideration, and giving the information related to the distribution and binding intensity of water molecules to ensure the physicochemical and microbiological stability during the storage [1], in addition the product shelf life can be predicted studies on sorption isotherms are carried out by mathematical modeling [8], eight mathematical models (in the literature) empirical and semi-empirical based on more or less physical bases $[1,4,9]$, describing the correlation of water content with balance with the water activity of the products. among these models: GAB [10], modified BET [11], Henderson-Thompson [12], modified Halsey [12], modified Oswin [12], Peleg [11]. GAB is the most widely used model for various foods $[8,13]$.

\section{MATERIALS AND METHODS}

\subsection{Sampling}

The tomato (Lycopersicon esculentum) fruits selected by this study were a local variety grown in the Adrar region. We made three tomato slice sample of $10 \mathrm{~g}$ dried tomato (in the indirect dryer). Tomatoes were selected for their absence of defects, firmness, and uniformity of size, symmetry and red color. The dried tomato was collected and transported under aseptic conditions in a cooler at $4{ }^{\circ} \mathrm{C}$ for microbiological and physicochemical analyzes [14].

\subsection{Description of experimental techniques of isotherms}

Table 1. Standard values of relative humidity

\begin{tabular}{ccc}
\hline Salts & Solubility (g /) & Masses mi (g) \\
\hline $\mathrm{KOH}$ & 100 & 132 \\
$\mathrm{KF}$ & 449 & 35.9 \\
$\mathrm{MgCl}_{2}$ & 542 & 43.3 \\
$\mathrm{~K}_{2} \mathrm{CO}_{3}$ & 1120 & 134.4 \\
$\mathrm{NaCl}$ & 359 & 28.7 \\
$\mathrm{KCl}$ & 340 & 27.2 \\
$\mathrm{BaCl}_{2}$ & 360 & 28.8 \\
$\mathrm{~K}_{2} \mathrm{SO}_{4}$ & 120 & 9.6 \\
\hline
\end{tabular}

Different techniques were reported to obtain the water isotherms for food products, while the gravimetric technique was the most used in literature $[1,4,15]$, which it is based on the saturated saline solution method using the following solutions $\left(\mathrm{KOH}, \mathrm{MgCl}_{2}\left(6 \mathrm{H}_{2} \mathrm{O}\right), \mathrm{K}_{2} \mathrm{CO}_{3}, \mathrm{NaNO}_{3}, \mathrm{KCl}\right.$, and $\mathrm{BaCl}_{2}\left(6 \mathrm{H}_{2} \mathrm{O}\right)$ [11, 12] with moisture content ranging from $(5.5 \%)$ to $(95.8 \%)$ as indicted in (Table 1$)$, so, in order to get the isotherm points, the samples of tomato was put in an enclosure maintained at temperature $(\mathrm{T})$ and at a relative humidity $(\mathrm{Hr})$ of the constant air solar drying, then again, The consultation of different values of solubility of salts and their masses in order to have a prior idea was consulted, and suited with the preparation of these salts [16]. To getting the solution solubility, the salts were dissolved in a bottle containing 120 $\mathrm{ml}(1 / 5)$ volume bottle of distilled water using a precision digital display scale of 0.01 . The agitation of the solution solubility different salts was indispensable for the homogenization of these solutions (Table 2) [5, 11].

Table 2. Used salts and saturated masses solubility

\begin{tabular}{cc}
\hline Models names & Models equations \\
\hline GAB & $\mathrm{Xeq}=\frac{A \cdot B \cdot C \cdot A w}{[1-B \cdot A w] \cdot[1+B \cdot A W+B \cdot C \cdot A w]}$ \\
BET modified & $\mathrm{Xeq}=\frac{(A+B T) \cdot C \cdot A w}{[1-A w] \cdot[1-A w+C \cdot A w]}$ \\
\hline
\end{tabular}

\subsection{Models descriptions of the sorption isotherms}

For the calculation of model sorption isotherms, several mathematical models are indicated in the literature. These models are based on equations physics, which explain the relationship between equilibrium moisture content, equilibrium relative humidity, and temperature. For this study, we have focused on tow essential models for the adjustment and modeling of tomato sorption isotherm in three temperatures 40,50 and $60^{\circ} \mathrm{C}$, the models and equation mathematical are shown in (Table 3 ).

Table 3. Mathematical models used to describe sorption Isotherms $[10,16]$

\begin{tabular}{cccc}
\hline Salts & $\mathbf{T}=\mathbf{4 0}^{\circ} \mathbf{C}$ & $\mathbf{T}=\mathbf{5 0}^{\circ} \mathbf{C}$ & $\mathbf{T}=\mathbf{6 0}^{\circ} \mathbf{C}$ \\
\hline $\mathrm{KOH}$ & 5.7 & 5.7 & 5.5 \\
$\mathrm{KF}$ & 22.7 & 20.8 & 20.8 \\
$\mathrm{MgCl}_{2}$ & 30.5 & 30.5 & 29.3 \\
$\mathrm{~K}_{2} \mathrm{CO}_{3}$ & 42.3 & 45.6 & 45 \\
$\mathrm{NaCl}$ & 74.7 & 74.4 & 74.5 \\
$\mathrm{KCl}$ & 82.3 & 81.2 & 80.3 \\
$\mathrm{BaCl}_{2}$ & 88.2 & 88.2 & 89.2 \\
$\mathrm{~K}_{2} \mathrm{SO}_{4}$ & 96.4 & 95.8 & 95.7 \\
\hline
\end{tabular}

\subsection{Curve modeling}

The curve Experts software (curve Expert 1.4 and Origin 6) was used for testing the equations of models on water content (Xeq) curves as a function of water activity (aw) for samples of tomato at temperatures of 40,50 and $60^{\circ} \mathrm{C}$ [5]. These program gives different models with the curves in the order of standard error values (S) and Coefficient of determination $\left(\mathrm{r}^{2}\right)$.

\subsection{Description indirect solar dryer}

Solar drying is an effective technique, easily controllable and inexpensive for the conservation of perishable products. This method does not use expensive equipment. It is therefore an interesting alternative $[17,18]$.

The indirect solar dryer described below was built in URER/ MS institution as a result of various experiments (Figure 2). It is a hand-made wooden dryer that uses simple, inexpensive equipment and materials and that are readily available on the market. This dryer consists of two elements such as the solar collector which composed of the glass cover and an absorber plate of metal of thickness $2 \mathrm{~mm}$ with black coating and the indirect drying chamber of parallelepiped form with a polystyrene plate isolating between their walls which equipped with the trays $[5,19]$. 


\subsection{The steps of the solar drying process}

Fresh tomatoes of approximately the same size and maturity were washed with tap water, then cut into two slices, then spread the same mass on the trays. The trays were placed in an indirect dryer. the process of drying was stopped until the stabilization of weigh [5].

\subsection{Diagram of dried tomato production}

The production line for dried tomato is illustrated in Figure 1. It includes the following steps: (1) fresh tomatoes (2) Washing, (3) cutting, (4) arrangement on racks, (5) drying (6) microbiological and physicochemical analysis,(7) packaging and (8) storage.

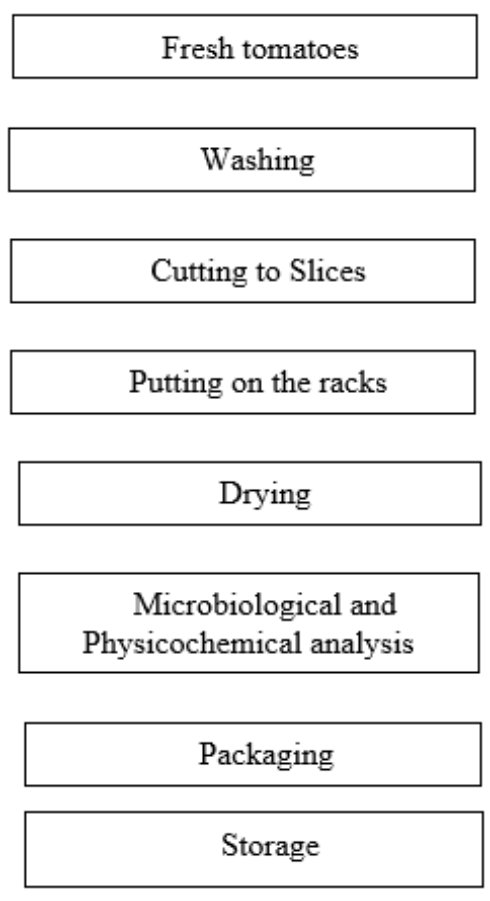

Figure 1. Production chart of the dried tomatoes

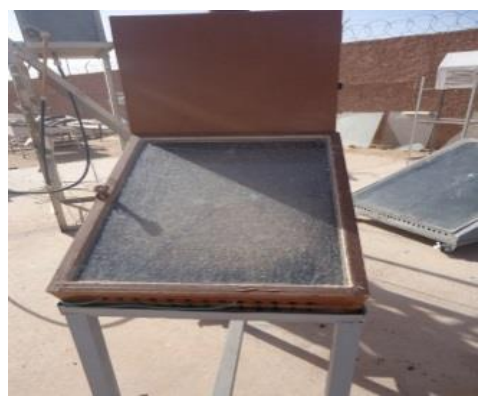

(a)

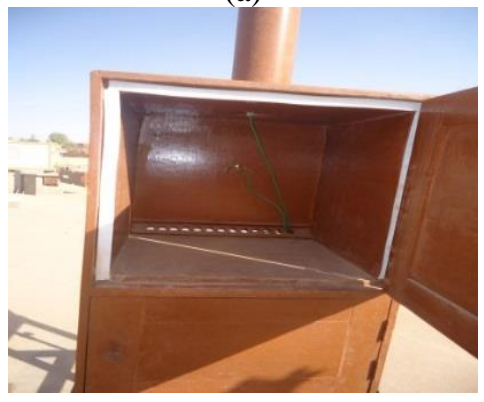

(b)

Figure 2. The indirect solar dryer: (a) front view, (b) back view

\subsection{Microbiological analysis}

A $10 \mathrm{~g}$ portion of each sample is aseptically cut and then thoroughly milled using the stomacher mill, decimal dilutions are carried out using a 1/4 diluted Ringer solution previously sterilized. The microbiological analysis included the assessment of total contamination by enumeration of total aerobic mesophilic and detection of spoilage bacteria including E. coli, Staphylococcus aureus, Salmonella Typhi and Clostridium perfringens [20, 21].

2.8.1 Enumeration of Total Aerobic Mesophilic Flora (FMAT)

The Total mesophilic germs count was performed after appropriate dilutions of the sample in the buffered peptone broth and then inoculation on Plate Count Agar (PCA) medium and incubation at $30^{\circ} \mathrm{C}$ for 72 hours.

\subsubsection{Research of total and fecal Coliform (C T). (C F)}

The enumeration of total coliforms is performed on VRBG medium and incubated at $30^{\circ} \mathrm{C}$ for total coliforms and at $44^{\circ} \mathrm{C}$ for faecal coliforms, the count of red colonies is performed after 24 hours of incubation. (Standards NM 08.0.124) [22].

\subsubsection{Research of Staphylococcus aureus (S a)}

The enumeration is carried out on Giolitti cantonii medium after incubation at $37^{\circ} \mathrm{C}$. for 24 hours.

\subsubsection{Research of Salmonella Typhi (S T)}

First day Pre-enrichment: Collect 25 gr of the product to be analyzed in a sterile stomacher bag containing $225 \mathrm{ml}$ of buffered peptone water. Grind this suspension in a Stomachertype mill, transfer it to a sterile flask which is incubated at $37^{\circ} \mathrm{C}$ for 18 hours.

Second day Enrichment: should be carried out on two different selective media, namely Rappaport Vassiliadis medium and Selenite-Cysteine medium, and incubated at $37^{\circ} \mathrm{C}$.

Third day Isolation: The isolation should be carried out on two different agar media, namely, the Hektoen agar medium and the bright green and phenol red lactose Bilberry agar, then all the seeded plates will be incubated at $37^{\circ} \mathrm{C}$. For $24 \mathrm{~h}$.

Fourth day Reading the dishes and Identification: The Salmonella are presented as follows: pink colonies surrounded by a red zone on BLVBRP agar and colonies often gray blue with black centre on Hektoen agar.

\subsubsection{Research Clostridium sulfito - reducer (C sr)}

Clostridium sulphito-reducers were counted after heating 10 $\mathrm{ml}$ of the mother solution au bath at $80^{\circ} \mathrm{C}$ for 10 minutes to select the spores and seeding in Depth $(1 \mathrm{ml})$ and double layer TSN agar (Trypticase -Sulfite-neomycin). After incubation of the Petri dishes at $37^{\circ} \mathrm{C}$ for 24 hours under anaerobic conditions.

\subsubsection{Yeasts and molds}

Yeasts and moulds were counted on OGA medium by inoculation of the surface medium with $0.1 \mathrm{ml}$ of the stock suspension and its dilutions and incubation of the Petri dishes at $30^{\circ} \mathrm{C}$ for 72 hours.

\subsection{Physico-chemical analysis}

\subsubsection{Determination of the water content}

The dry matter of the products is determined by evaporation of their moisture without causing the volatilization of the constituent substances of the product. It is obtained by drying 
in an oven at $105^{\circ} \mathrm{C}$.

Of a constant weight, the water content is calculated according to the following formula:

$$
\mathrm{H} \%=\frac{\left(\mathrm{M}_{1}-\mathrm{M}_{2}\right)}{\mathrm{P}} .100
$$

$\mathrm{M}_{1}$ : the mass of capsule + fresh material before baking (g); $\mathrm{M}_{2}$ : the mass of capsule + fresh material after steaming (g); $\mathrm{P}$ : the test sample mass (g).

\subsubsection{Determination of ash content}

The tomato $(5 \mathrm{~g})$ is calcined at $550^{\circ} \mathrm{C}$ in a muffle furnace until a whitish ash of constant weight is obtained. The percentage of the organic material MO is given by the following formula:

$$
\mathrm{MO} \%=\frac{\left(M_{1}-M_{2}\right)}{P} .100
$$

MO\%: Organic matter.

$\mathrm{M}_{1}$ : the mass of the capsule + test portion (g).

$\mathrm{M}_{2}$ : the mass of the capsule + ashes (g).

$\mathrm{P}$ : the mass of the test sample (g).

The ash content $(\mathrm{Tc})$ is calculated as follows:

$$
\mathrm{T}=100-\mathrm{MO} \%
$$

\subsubsection{Determination of water activity}

The water activity is measured on small samples of fresh and dry meat by the measuring device Aw (water activity).

\subsubsection{Determination of $\mathrm{pH}$}

Determination of $\mathrm{pH}$ is essential for the control of microbial fermentation. Its variation tells us about the metabolic activity of the microflora. After grinding the tomato is added at least two or three times its volume of distilled water in a beaker and then heated for $30 \mathrm{~min}$ with stirring. The $\mathrm{pH}$ is determined by taking care that the electrode of the $\mathrm{pH}$ meter is completely immersed in the solution. The determination of the $\mathrm{pH}$ is carried out in our conditions by a direct reading using a $\mathrm{pH}-$ meter.

\section{RESULTS AND DISCUSSION}

As a result, the determination of desorption isotherms obtained at a temperature of $40,50,60^{\circ} \mathrm{C}$ are indicated in Figure 3 . We note that the increase in equilibrium water was related to the increasing of activity water at constant temperature, and are a sigmoidal appearance according to the classification of BET. These results are similar when compared to other behavior food agriculture proved by author such as [23]. In these figures, we notice that the bending on sorption isotherms in the water activity was in 65-80.

According in the many results related to the curves of the sorption isotherms of food agriculture, the curves obtained were divided to three zones as following:

- The first zone of water activity ranged from (0.05) to $(0.50)$, which characterized by the lowest amount of water referring to active sites in the molecules of polar groups.

- The second zone ranged from (0.5) to (0.75) is related to the reaction of biochemical, while, the micropores and macropores were fills when the moisture content arrives at a high level.

- The latest zone was ranged from $(0.75)$ to $(0.90)$ which mischaracterized by the growth of pathogens microorganisms and yeasts and molds.

- The Figures 3, 4 and 5 show the application determention of desorption of the tomato at temperature 40 (a), 50 (b) and 60 (c) simulated with GAB and BET models. The obtained data confirmed the proportion of moisture content of tomato. Our results of two models GAB and BET are provided good curves with lowing standard error and high correlation coefficient when compared with other models.

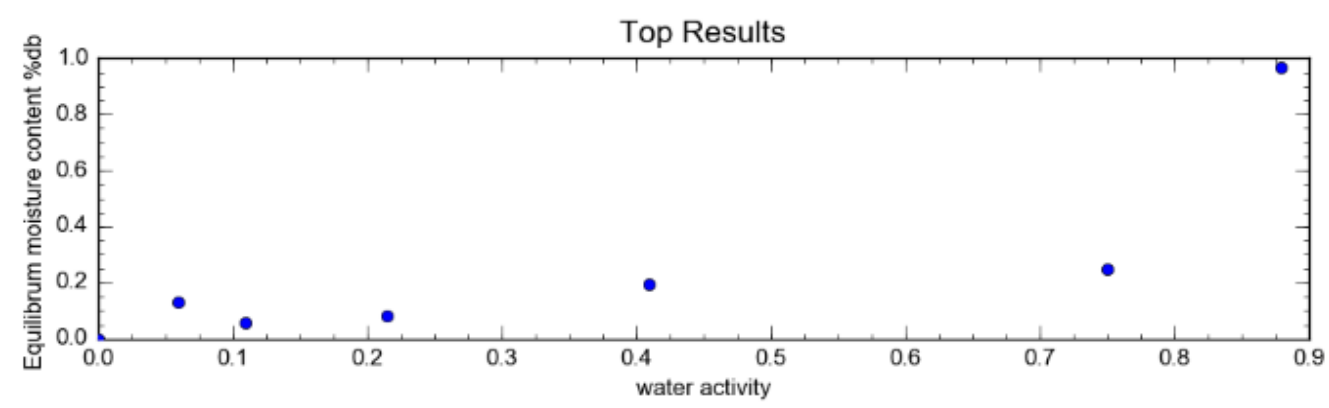

(a)

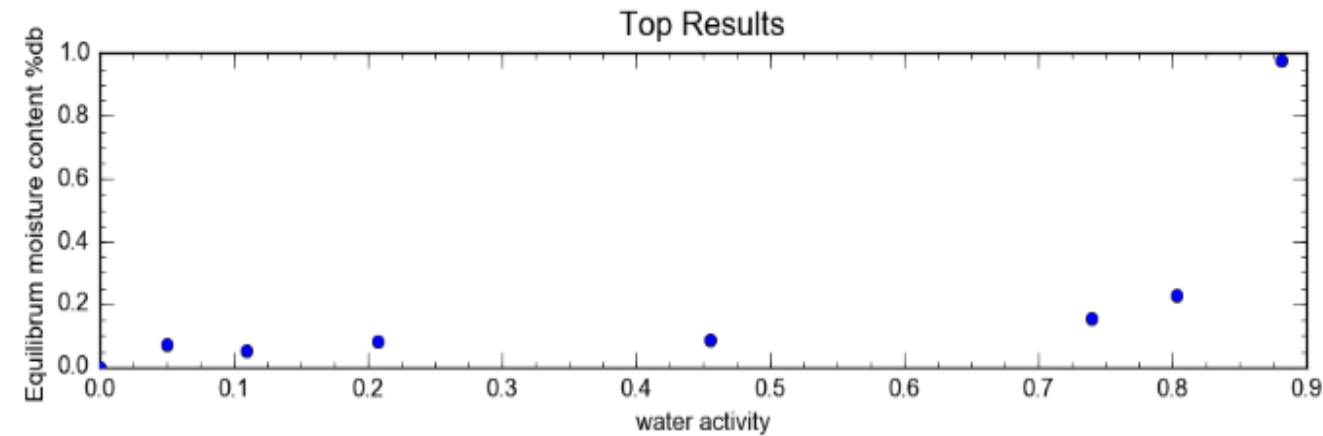

(b) 


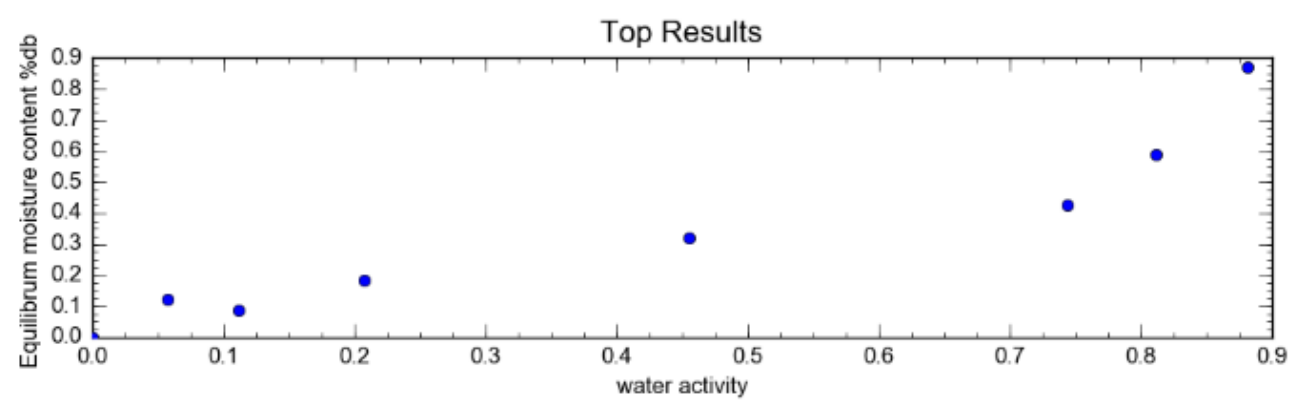

(c)

Figure 3. Experimental isotherms of tomato at 40 (a), 50 (b) and $60^{\circ} \mathrm{C}$ (c)

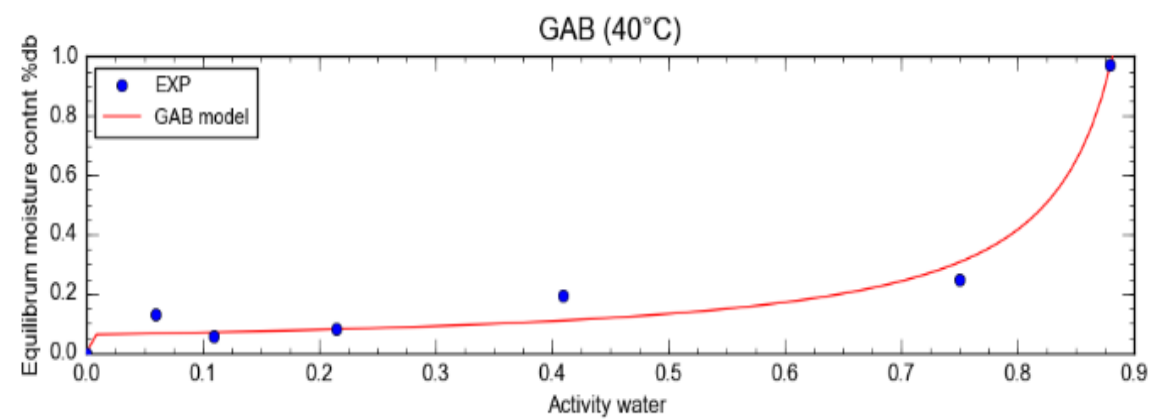

(a)

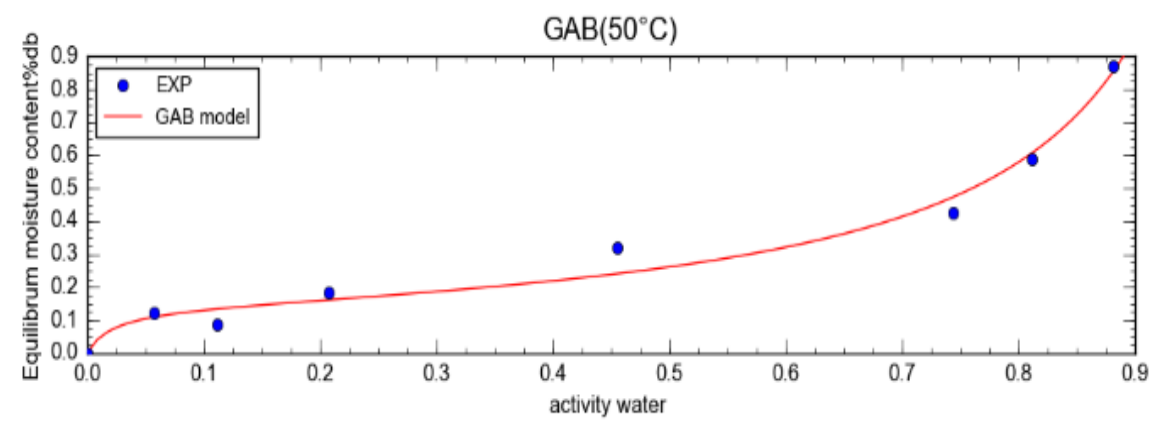

(b)

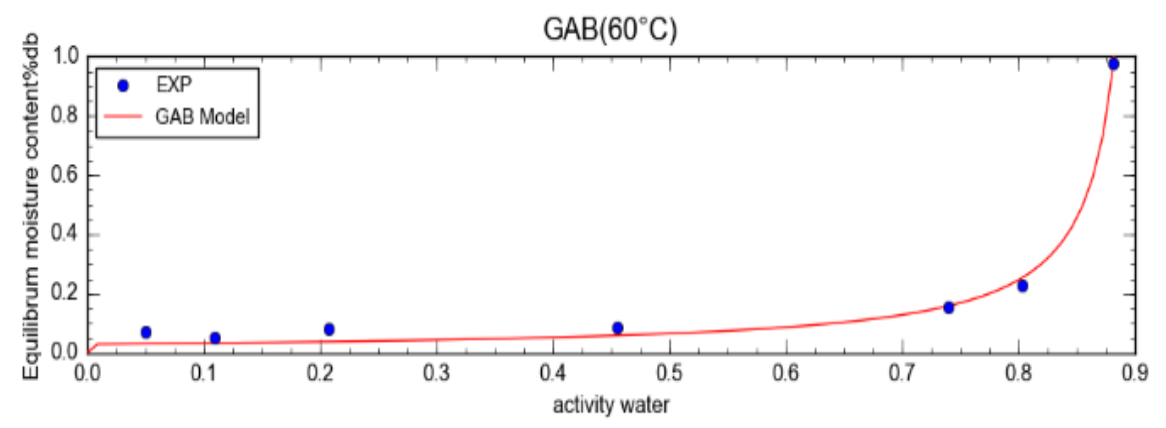

(c)

Figure 4. Desorption isotherms of tomato at 40 (a), 50 (b) and $60^{\circ} \mathrm{C}$ (c) simulated by the GAB model

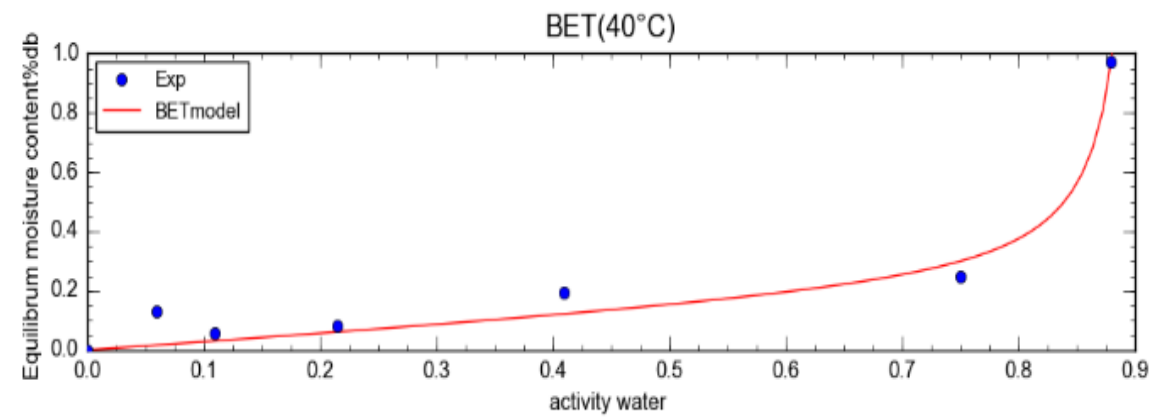

(a) 


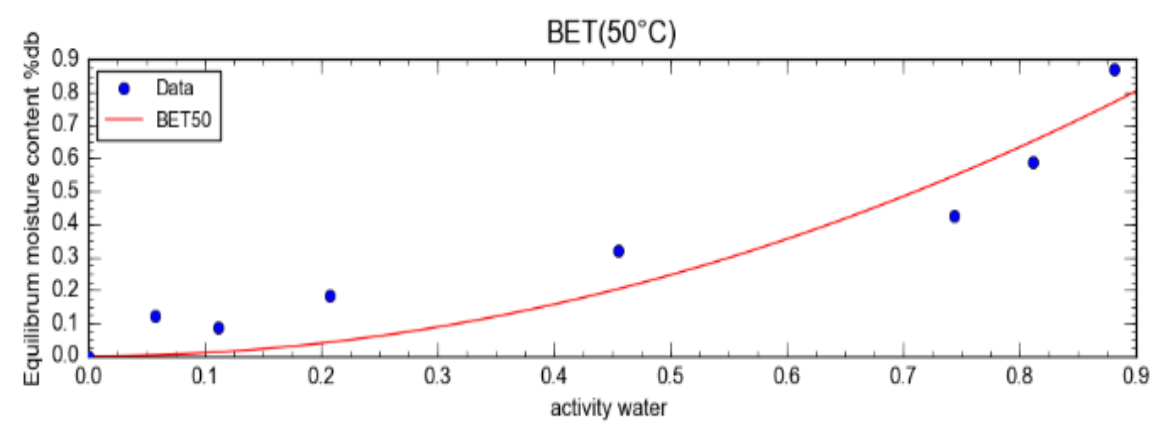

(b)

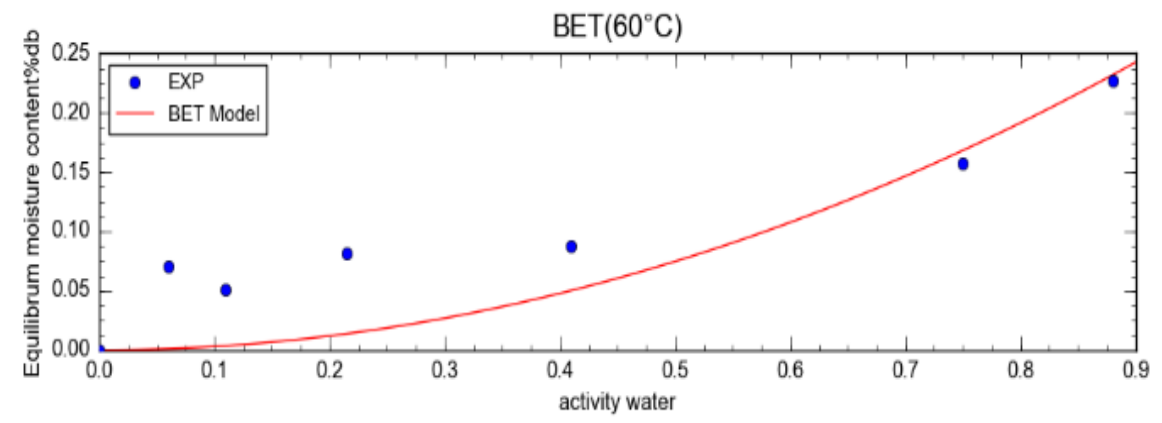

(c)

Figure 5. Desorption isotherms of tomato at 40 (a), 50 (b) and $60^{\circ} \mathrm{C}$ (c) simulated by the BET model

\subsection{Isosteric sorption heats determination}

To determinate Isosteric heat of sorption, according to GAB model, we use the water content value depending on water activity values at each fixed temperature by applying the following equation:

$$
\operatorname{Ina}_{w}=\left(\frac{1}{T}\right)
$$

for fixed equilibrium points using the Using ClausiusClapeyron Equation, the net isosteric heat of sorption can be calculated at each value of equilibrium moisture content from the slope of the isosteric curves which is equal to:

$$
\mathrm{Q}_{\mathrm{st}}=\mathrm{f}(\mathrm{Xeq})
$$

The desorption isosteres for tomato are illustrated in The evaluation parameters of the empirical equation with the Levenberg-Marquardt method was effected using the Nonlinear regression, the obtained results were in agreement to other works such as Tsami et al. [1] applied for other food product Figure 6 and 7, where we notice that the increase in net desorption heat is compatible with the increases of the degree dehydration as the degree of dehydration increases which is relating to existence highly active polar sites in the product that are been covered by water molecule forming the molecular layer $[2,24]$.

\subsection{Drying kinetic}

The Figure 8 indicates that the initial weight of tomato is 0.5 $\mathrm{kg}$ which contains a $90 \%$ water from the total weight. The weight of tomato has exhibited a reduction in the weight from 0.5 to $0.25 \mathrm{~kg}$ during 20 hours and stabilizes until 30 hours of drying.

The weight product decrease related to meteorological conditions. The fast-drying is depending to the hotter season which reflect the high temperature in the dryer and drying speed. In the final process of drying, the products were packaging under vacuum and storage until using (Figure 9).

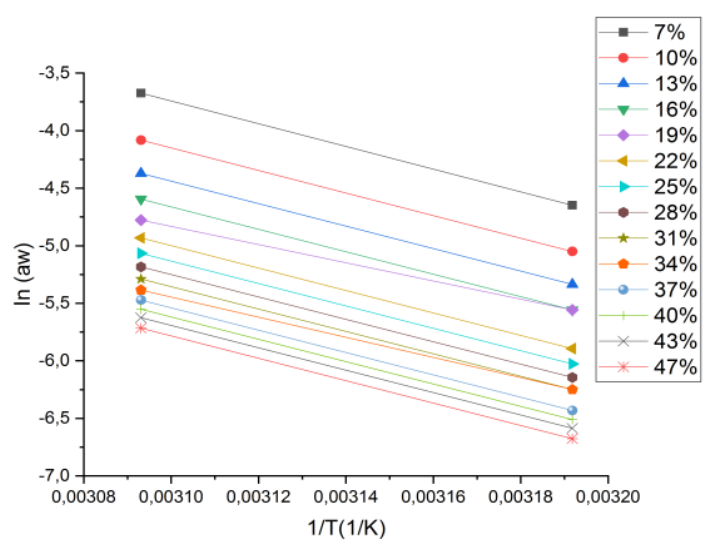

Figure 6. Desorption Isosteric for tomato

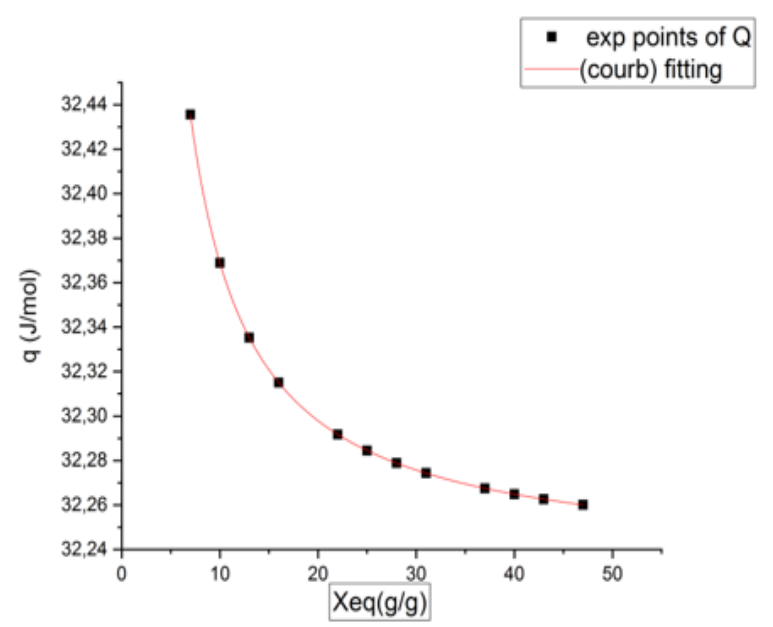

Figure 7. Net Isosteric heat desorption for tomato according to equilibrium water content 


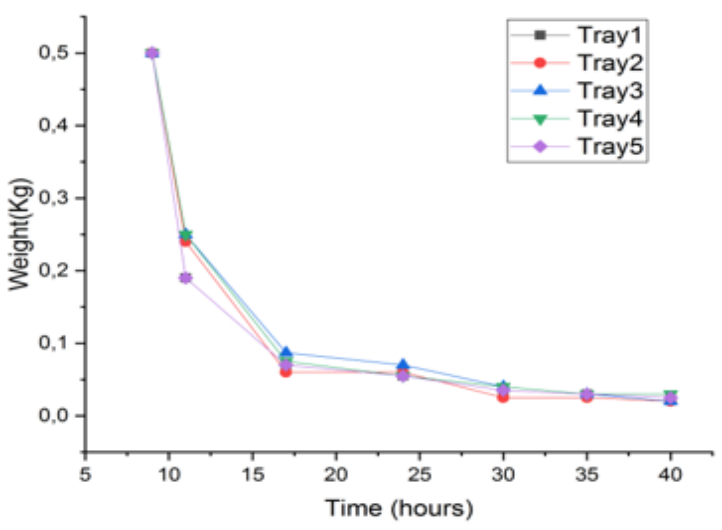

Figure 8. Evolution of weight of dried tomato during the drying process

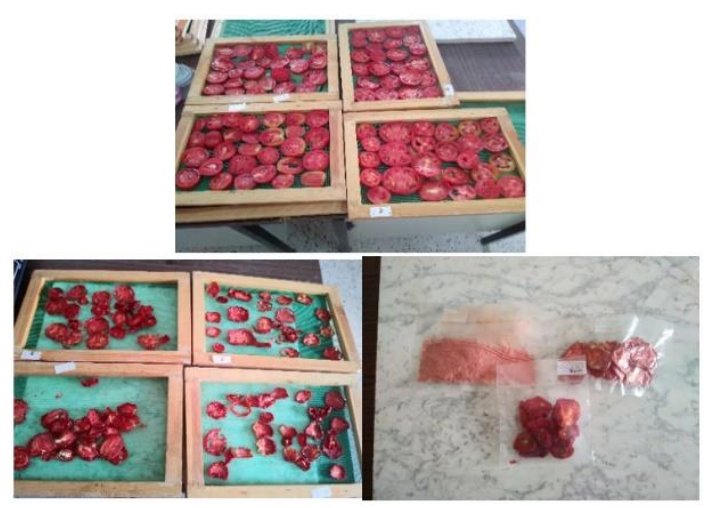

Figure 9. Trays loaded with tomato: before drying, after drying, packaging of dried products

\subsection{Hygienic characteristic of dried tomatoes}

The results of the hygienic quality of the dried tomato production line in a direct solar dryer was showed in the Table 4 , it can be seen that the dried product has been contaminated by total aerobic mesophilic with a level of $3.1 \times 10^{2}$ grams $/ \mathrm{gr}$. whereas the standard tolerates of $10^{5}$ per gram and $15 \times 10^{3}$ grams/gr for total coliforms with tolerates of $10^{4}$ of and Absence for fecal coliforms with tolerates of 10 and $2.1 \times 10^{2}$ grams/gr for yeasts and moulds with tolerates of $10^{2}$. The Analyses respectively revealed that the absence of germ for Staphylococcus aureus with tolerates $10^{2}$ grams/gr and Clostridium sulfito-reducteurs with tolerates of $10 \mathrm{grams} / \mathrm{gr}$ and also for Salmonella Typhi. This shows a good level of hygiene for the production of dried tomatoes.

Table 4. Microbiological analyzes of tomato dried

\begin{tabular}{ccc}
\hline Microbiological analysis & $\begin{array}{c}\text { Value } \\
\text { (ufc/gr) }\end{array}$ & $\begin{array}{c}\text { Usual } \\
\text { value } \\
\text { (ufc/gr) }\end{array}$ \\
\hline Total mesophilic germs & $3.1 \times 10^{2}$ & $10^{5}$ \\
Total Coliforms & $15 \times 10^{3}$ & $10^{4}$ \\
Fecal coliforms & 00 & 10 \\
Yeasts and molds & $2.1 \times 10^{2}$ & $10^{3}$ \\
Salmonella Typhi & 00 & Absence \\
Staphylococcus aureus & 00 & $10^{2}$ \\
Clostridium sulfito-reducteurs & 00 & 10 \\
\hline
\end{tabular}

\subsection{Physicochemical characteristics of dried tomato}

The main physicochemical characteristics of the dried tomato are summarized in the Table 5. The dry matter content of the dried tomato is lower with a value of $9.63 \%$, which means that the solar drying evaporates the quantity of dried tomato water. The water activity of dried tomato equal to 0.41 and assay of ash equal of 5.71, this confirms the development of micro-organisms is almost inhibited by the cessation of the enzymatic reaction. The $\mathrm{pH}$ is relatively low $(\mathrm{pH} \leq 4.3)$, and that's an advantage. Indeed, this level of $\mathrm{pH}$ is considerably reduced the rate and range of microorganism that can develop on the Product such as Salmonella and Clostridium and Staphylococcus aureus [25].

Table 5. Physicochemical analyzes of tomato dried

\begin{tabular}{cc}
\hline Physicochemical analysis & Value (\%) \\
\hline Dry matter & 9.63 \\
pH & 4.10 \\
Water activity & 0,41 \\
Assay of ash & 5.71 \\
\hline
\end{tabular}

\section{CONCLUSION}

Solar drying is an effective method for preserving food products such as tomatoes and giving a product closer to the fresh product, on the side of the nutritional value of physiochemical appreciation. With regard to hygienic quality, it is confirmed that the quality of the dried tomato is satisfactory and does not present any risk to the health of the consumer, furthermore, the experimental curves of the desorption isotherms of the tomato is necessary to the drying field and that the understanding of the equilibrium between the drying air and the wet product to be dried which is imperative. The models GAB and BETA are suitable to the description isotherms of tomato, Finally, the smoothing of the experimental points allowed us to find experimental equations characterizing the desorption of the tomato at $40^{\circ} \mathrm{C}, 50^{\circ} \mathrm{C}$ and $60^{\circ} \mathrm{C}$.

\section{ACKNOWLEDGMENT}

The authors acknowledge the support provided by 'Unité de Recherche en Energies Renouvelables en Milieu Saharien (URER/MS), Centre de Développement des Energies Renouvelables (CDER)' of Adrar, Algeria to make and finalize this work.

\section{REFERENCES}

[1] Jangam, S.V., Law, C.L., Mujumdar, A.S. (2010). Drying of Foods Vegetables and Fruits. Published in Singapore.

[2] Larbi, A.A., Loumani, A., Ahmed, M., Tigani, C. (2019). Experimental measurement of moisture sorption isotherms and isosteric heat of palm hearts (Jomare) harvested in the Algerian Sahara. Instrumentation Mesure Metrologie, 18(3): 297-304. https://doi.org/10.18280/i2m.180310

[3] Kouhila, M., Belghit, A., Daguenet, M., Boutaleb, B.C. (2001). Experimental determination of the sorption isotherms of mint (Mentha viridis), sage (Salvia officinalis) and verbena (Lippia citriodora). Journal of Food Engineering, 47(4): 281-287. 
https://doi.org/10.1016/S0260-8774(00)00130-8

[4] Bennaceur, S., Draoui, B., Touati, B., Benseddik, A., Saad, A., Bennamoun, L. (2015). Determination of the moisture-sorption isotherms and isosteric heat of henna leaves. Journal of Engineering Physics and Thermophysics, $\quad 88$ : 52-62. https://doi.org/10.1007/s10891-015-1167-9

[5] Chaouch, W.B., Khellaf, A., Mediani, A., Slimani, M., Loumani, A., Hamid, A. (2018). Experimental investigation of an active direct and indirect solar dryer with sensible heat storage for camel meat drying in Saharan environment. Solar Energy, 174: 328-341. https://doi.org/10.1016/j.solener.2018.09.037

[6] Iglesias, H.A., Chirife, J. (1982). Water sorption parameters for food and food components. Handbook of Food Isotherms, Academic Press, pp. 23-87.

[7] Ahouannou, C., Jannot, Y., Lips, B., Lallemand, A. (2000). Characterization and modelling of drying of three tropical products: Cassava, ginger and okras. Sciences des Aliments, 20(4/5): 413-432. https://doi.org/10.3166/sda.20.413-432

[8] Tsami, E. (1991). Net isosteric heat of sorption in dried fruits. Journal of Food Engineering, 14(4): 327-335. https://doi.org/10.1016/0260-8774(91)90022-K

[9] Mediani, A., Moungar, H., Larbi, A.A., Loumani, A., Chaouch, W.B., Djaber, A. (2019). The isothermal sorption measurement and the isosteric heats determinations for the South Algerian date varieties. Instrumentation Mesure Métrologie, 18(4): 389-396. https://doi.org/10.18280/i2m.180408

[10] Lutovska, M., Mitrevski, V., Geramitcioski, T., Mijakovski, V., Andreevski, I. (2016). Water activity vs. equilibrium moisture content vodena aktivnost nasuprot ravnotežne. Biblid, 20(2): 69-72.

[11] Iglesias, H. (2012). Handbook of Food Isotherms: Water Sorption Parameters for Food and Food Components. Elsevier. https://doi.org/10.1016/B978-0-12-3703804.X5001-4

[12] Mitrevski, V., Mitrevska, C., Mijakovski, V., Pavkov, I.S., Geramitcioski, T. (2017). Mathematical modelling of the sorption isotherms of quince. Thermal Science, 21(5):

1965-1973. https://doi.org/10.2298/TSCI170118095M

[13] Goula, A.M., Adamopoulos, K.G. (2003). Spray drying performance of a laboratory spray dryer for tomato powder preparation. Drying Technology, 21(7): 12731289. https://doi.org/10.1081/DRT-120023180

[14] Fagbohoun, O., Kiki, D.G. (1999). Aperçu sur les principales variétés de tomate locale cultivées dans le sud du Bénin. Bulletin de la Recherche Agronomique Numéro, 24: 10-21.

[15] Goula, A.M., Karapantsios, T.D., Achilias, D.S., Adamopoulos, K.G. (2008). Water sorption isotherms and glass transition temperature of spray dried tomato pulp. Journal of Food Engineering, 85(1): 73-83. https://doi.org/10.1016/j.jfoodeng.2007.07.015

[16] Kiranoudis, C.T., Maroulis, Z.B., Tsami, E., MarinosKouris, D. (1993). Equilibrium moisture content and heat of desorption of some vegetables. Journal of Food engineering, 20(1): 55-74. https://doi.org/10.1016/02608774(93)90019-G

[17] Semmar, D., Betrouni, S., Lafri, D. (1998). Etude et Réalisation d'un Capteur Solaire à Air'. Revue des Énergies Renouvelables (CDER), pp. 1112-2242.
[18] Van den Berg, C. (1984). Description of water activity of foods for engineering purposes by means of the GAB model of sorption. In B.M. McKenna (Ed.), Engineering and Foods (pp. 311-321). London: Elsevier.

[19] Talla, A., Jannot, Y., Nkeng, G.E., Puiggali, J.R. (2005). Experimental determination and modeling of sorption isotherms of tropical fruits: Banana, mango, and pineapple. Drying Technology, 23(7): 1477-1498. https://doi.org/10.1081/DRT-200063530

[20] Akil, L., Ahmed, B. (2018). Rep PCR characterization of lactic acid bacteria isolated from sheep's milk in Algeria and assessment of their probiotics potential. Asian Journal of Microbiology, Biotechnology \& Environmental Sciences Paper, 20(3): 836-842.

[21] Čiplienè, A., Novošinskas, H., Raila, A., Zvicevic, E. (2015). Usage of hybrid solar collector system in drying technologies of medical plants. Energy Conversion and Management, 93: 399-405. https://doi.org/10.1016/j.enconman.2015.01.051

[22] Wilson, C.L., Wisniewski, M.E., Biles, C.L., McLaughlin, R., Chalutz, E., Droby, S. (1991). Biological control of post-harvest diseases of fruits and vegetables: Alternatives to synthetic fungicides. Crop Protection, $10(3)$ : 172-177. https://doi.org/10.1016/0261-2194(91)90039-T

[23] Nganhou, J. (1987). Coupled transfers of heat and matter in a thick bed drying. Thesis of the University of Poitiers.

[24] Maroulis, Z.B., Tsami, E., Marinos-Kouris, D., Saravacos, G.D. (1988). Application of the GAB model to the moisture sorption isotherms for dried fruits. Journal of Food Engineering, 7(1): 63-78. https://doi.org/10.1016/0260-8774(88)90069-6

[25] Houcine, M., Azzi, A., Youcef, S., Haida, A. (2018). Monthly fresh water yield analysis of three solar desalination units a comparative study in the south Algeria climatic condition. International Journal of Heat and Technology, 36(4): 1330-1335. https://doi.org/10.18280/ijht.360423

\section{NOMENCLATURE}

$\begin{array}{ll}\text { Aw } & \text { Water activity (dimensionless) } \\ \mathrm{r}^{2} & \text { Correlation coefficient }[-] \\ \mathrm{T} & \text { Temperature }\left[{ }^{\circ} \mathrm{C}\right] \\ \mathrm{Xeq} & \text { Equilibrium moisture content }[\mathrm{kg} / \mathrm{kg}] \\ \mathrm{Hr} & \text { Relative humidity } \% \\ \mathrm{Q} 0 & \text { Model coefficients }\end{array}$

$\mathrm{A}, \mathrm{B}, \mathrm{C}, \mathrm{K}, \mathrm{q}, \mathrm{S} \quad$ Net isosteric heat of desorption [J/mol]

$\mathrm{p}$

$\mathrm{MO} \%$

Tc

CT

$\mathrm{CF}$

$\mathrm{Sa}$

$\mathrm{St}$

Csr

M2

FMAT

M1 the mass of the test sample $(\mathrm{g})$.

Organic matter

Ash content

Total Coliform

Fecal coliform

Staphylococcus aureus

Salmonella Typhi

Clostridium sulfito - reducer

The mass of the capsule + ashes $(\mathrm{g})$.

Enumeration of Total Aerobic Mesophilic Flora.

The mass of capsule + fresh material before baking. 